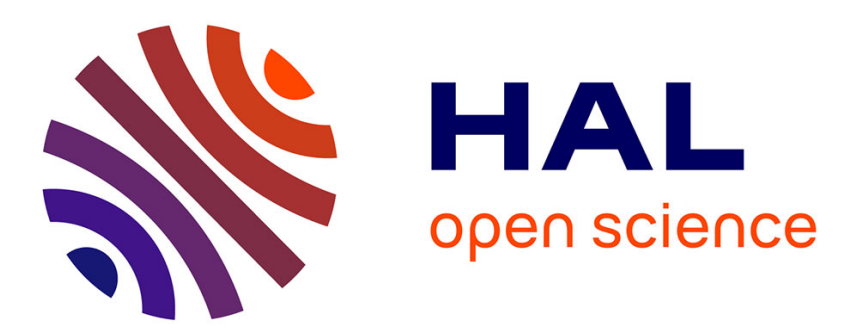

\title{
The direct and indirect effects of core and peripheral social capital on organizational performance
}

\author{
Fabio Fonti, Massimo Maoret
}

\section{To cite this version:}

Fabio Fonti, Massimo Maoret. The direct and indirect effects of core and peripheral social capital on organizational performance. Strategic Management Journal, 2016, 37, pp.1765 - 1786. 10.1002/smj.2409 . hal-01478950

\section{HAL Id: hal-01478950 \\ https://hal-rennes-sb.archives-ouvertes.fr/hal-01478950}

Submitted on 28 Feb 2017

HAL is a multi-disciplinary open access archive for the deposit and dissemination of scientific research documents, whether they are published or not. The documents may come from teaching and research institutions in France or abroad, or from public or private research centers.
L'archive ouverte pluridisciplinaire HAL, est destinée au dépôt et à la diffusion de documents scientifiques de niveau recherche, publiés ou non, émanant des établissements d'enseignement et de recherche français ou étrangers, des laboratoires publics ou privés. 


\title{
WHERE AND HOW MUCH DOES SOCIAL CAPITAL MATTER? CORE AND \\ PERIPHERAL RELATIONAL STABILITY AS DETERMINANTS OF \\ ORGANIZATIONAL PERFORMANCE
}

\author{
Fabio Fonti \\ ESC Rennes School of Business - Management and Organisation Department \\ 2 rue Robert d'Arbrissel - CS 76522 \\ 35065 Rennes Cedex - France \\ Phone: +33-2-99456805 - Email: fabio.fonti@esc-rennes.fr \\ Massimo Maoret \\ Boston College - Management and Organization Department \\ 430 Fulton Hall - 140 Commonwealth Ave. \\ Chestnut Hill, MA 02467 \\ Phone: (617) 552-0703 - Fax: (617) 552-4230 - Email: maoret@bc.edu
}

Keywords: Social capital, social networks, relational stability, core/periphery, organizational performance.

Running head: Relational stability and organizational performance

The authors contributed equally to this work and are listed alphabetically. We gratefully acknowledge Callen Anthony, Steve Borgatti, Emilio Castilla, Aleksis Gotsopoulos, Candace Jones, Michael O’Leary, Felipe G. Massa, Jon Morgan, Ray Reagans, Natalia Sarkisian, Giorgio Tsiotas, and the participants to the MIT Economic Sociology work group for their constructive suggestions. Special thanks to Fabrizio Montanari for his help in earlier phases of this project. All remaining errors are our own. 


\title{
WHERE AND HOW MUCH DOES SOCIAL CAPITAL MATTER? CORE AND PERIPHERAL RELATIONAL STABILITY AS DETERMINANTS OF ORGANIZATIONAL PERFORMANCE
}

\begin{abstract}
We examine where and how much social capital matters for organizational performance. Building on the social networks and shared experience literatures, we suggest that the effect of relational stability - a form of social capital deriving from stable work ties among organizational members - on organizational performance depends, in strength and functional form, on whether actors involved in stable dyads are located at the core or at the periphery of an organizational network. We also leverage the resource-based view of the firm to argue that, in highly interdependent settings, social capital may be more important for organizational performance than human capital. Results from a 45-year study of the National Basketball Association partially support our arguments, bearing important implications for strategic human resource practices.
\end{abstract}

Keywords: Social capital, social networks, relational stability, core/periphery, organizational performance. 
Firms and other organizations operating in competitive environments often adhere to the common belief that a strategy of recruiting top talent will help improve their performance. This conviction is supported by scholarly work in the strategic management (Barney, 1991) and economic (Becker, 1964) literatures, according to which individuals carry sets of skills and knowledge that can be transferred to the organization they join, resulting in increased organizational performance and competitive advantage. The rapid diffusion of this practice has led to a 'war for talent': a fierce competition among firms and organizations to secure the services of the most talented employees (Gardner, 2002).

However, growing evidence suggests that focusing predominantly on individual talent may not be as effective as one might expect (Subramaniam and Youndt, 2005), as shown by a recent study of the performance of financial analysts (Groysberg, Lee, and Nanda, 2008). Since tasks within organizations are becoming increasingly interdependent (Cohen and Bailey, 1997), these lower-than-expected returns on human capital may be due to the increasingly critical role played by the interactions that take place within organizational networks - as compared to the contribution of individual talent - in determining organizational performance (Solow et al., 2002). Indeed, scholars have recently shown that social networks have a strong influence on organizational performance (Tortoriello, Reagans, and McEvily, 2012), perhaps even greater than employees’ demographic characteristics (Reagans, Zuckerman, and McEvily, 2004), and have provided evidence that organizations perform better thanks to the social capital they accrue over time via stable internal work relations (Espinosa et al., 2007; Reagans, Argote, and Brooks, 2005).

Despite the recent progress achieved by this line of research, two important questions remain unanswered, both of which have relevant implications for strategic hiring and staffing decisions. First, it is unclear whether and how the impact of social capital on organizational performance varies depending on its location within the structure of a network. Focusing on 
relational stability - a type of social capital that emerges from stable, ongoing relationships between organizational members - we theorize and empirically demonstrate that stable dyads located in the network core (Cattani and Ferriani, 2008) have a stronger effect on performance than stable dyads involving members located elsewhere within the organizational network. We find that performance returns offered by core stable dyads are not only higher, but also decrease at a higher rate than peripheral ones.

Second, despite increasing evidence of the role that social capital plays in enhancing organizational performance, we still do not know how strong its effect is, especially compared to human capital. Drawing on the resource-based view of the firm (Wernerfelt, 1984; Barney, 1991), we argue that social capital might have a stronger overall effect on organizational performance than human capital, especially in highly interdependent settings. Comparing the relative influence of social vs. human capital on performance allows us to understand whether the current emphasis on individual skills that underlies the 'war for talent' is empirically justified, or if HR managers should give more consideration to building and/or retaining social capital in their selection and staffing practices (Pfeffer, 2001). We test our hypotheses in a longitudinal sample using data from the National Basketball Association (NBA) ranging from 1966 to 2012.

\section{THEORY}

\section{The role of social capital in determining organizational performance}

Human capital theory (Becker, 1964) posits that organizations whose members have greater skills and capabilities will outperform their competitors. However, organizational performance is not only affected by members' individual characteristics, but also by the relationships between them (Reagans et al., 2004). For instance, Groysberg and his colleagues have recently shown that highly productive financial analysts are, on average, unable to maintain the same high-level performance when hired by a new firm, possibly due to changes in their 
organizational social networks (Groysberg et al., 2008). The patterns and the stability of ties among co-workers can have important implications for performance, as organizational networks may affect both the flow of resources (Brass, 1984) and the coordination required to perform interdependent tasks.

These speculations hint at how social capital theory may offer a complementary perspective to human capital theory in explaining organizational performance. Social capital is the value that accrues to individuals and organizations from their relationships (Coleman, 1988; Leana and Van Buren, 1999). While this value may also derive from relationships across organizational boundaries (Somaya, Williamson, and Lorinkova, 2008), in this paper we focus only on the internal social capital emerging from ongoing relationships between incumbent employees (Payne et al., 2011). Thus, we follow the definition of social capital proposed by Payne and colleagues, who suggest that organizations 'derive social capital from the internal forces within their collective ... achieved primarily as the collective matures and strong recursive bonds develop between actors who interact frequently’ (2011: 494).

Research on social capital has emphasized the importance of its accumulation over time through the maintenance of stable social networks (Coleman, 1988; Walker, Kogut, and Shan, 1997): as McEvily and colleagues note, 'the stability of networks is a key source of their value as 'social structures, and the resources to which they provided access, accumulate rather than decay over time’' (McEvily, Jaffee, and Tortoriello, 2012: 548). Recursive and long-lasting ties between employees promote the creation of shared norms, common language, and trust (Coleman, 1988; Jones, Hesterly, and Borgatti, 1997; Krackhardt, 1992) which, by increasing the likelihood of standardization of practices and cooperative behaviors, improve coordination and performance (Leana and Van Buren, 1999; Taylor and Greve, 2006). The social capital embedded in stable ties might also serve to increase cohesion, improve employees’ buy-in into shared goals (Leana and Van Buren, 1999) and enhance their ability to 
coordinate their activities (Katz, 2001), thus contributing to improve organizational performance (Pfeffer, 2001; Pfeffer and Sutton, 2006; Payne et al., 2011). The stability of their relationships also leads organizational members to develop strong collective cognitive structures, such as transactive memory systems (Ren and Argote, 2011) and shared mental models (Gnyawali and Madhavan, 2001; Mohammed, Ferzandi, and Hamilton, 2010). These cognitive structures allow workers to develop shared understandings of the appropriateness of certain reactions to specific situations that, by facilitating the access to and flow of information, improve their ability to coordinate and lead to better outcomes (Gnyawali and Madhavan, 2001; Mohammed et al., 2010). Indeed, scholars have demonstrated that organizations whose members sustain stable work relations over time perform better (Pfeffer and Sutton, 2006), an effect found in contexts as diverse as surgery (Reagans et al., 2005), mining (Goodman and Leyden, 1991), and software development (Huckman, Staats, and Upton, 2009).

\section{Relational stability and network structure: A core/periphery view}

Given the relevance of stability and accumulation over time in the development of social capital, in this paper we primarily focus on relational stability - 'the extent to which ties remain in the network over time' (Cummings and Higgins, 2006: 42) - as a critical form of social capital that positively affects organizational performance. Despite recognizing that relational stability can result in positive performance returns, extant research assumes that all organizational members are structurally equal when accounting for the performance implications of stability (Gardner, Gino, and Staats, 2012). Thus it remains unclear whether (and the extent to which) such performance outcomes might be contingent on characteristics of organizational networks such as their structure, and on the distribution of relational stability within it. For instance, Berman and colleagues suggested that the beneficial tacit knowledge generated by members' stability accumulates in an organization's ‘collective mind', but left for future research the task of teasing out how such knowledge is distributed 
within the organizational network (Berman, Down, and Hill, 2002: 28). Reagans and colleagues picked up this challenge and showed that 'knowledge is relationship specific' and is thus embedded in the relations between employees (Reagans et al., 2005: 877) rather than in a generic 'collective mind'. However, they did not investigate whether stable relationships among actors located in different parts of the network differ in how they affect organizational performance.

In this paper, we propose that the network location of stable ties does indeed matter and theorize how the influence of relational stability on performance is contingent on the network position of the individuals involved in stable dyads. Our reasoning is grounded in two considerations. First, the benefit of relational stability lies in facilitating the coordination of interdependent tasks (Harrison et al., 2003). Stability between dyad members underpins the development of the tacit knowledge necessary to effectively manage the high levels of task interdependence typical in networks (Reagans et al., 2005; Harrison et al., 2003). For instance, in the context of surgical hip-replacement teams, Reagans and colleagues found that coworkers who shared work experiences over time develop 'relationship-specific heuristics that enhance how well people performing distinct roles interact with each other', a form of tacit knowledge that is embedded in such ties and which improves workers' coordination and performance (Reagans et al., 2005: 872). Thus we might expect relational stability to be more relevant where the level of interdependence is higher.

Our second consideration is that the level of task interdependence is heterogeneous across an organizational network and is likely to peak among workers who are at the core of the organization (Siggelkow, 2002). Network and organizational scholars have proposed a core/periphery model (Cummings and Cross, 2003; Cattani and Ferriani, 2008) to represent organizational structures with different internal degrees of interdependence, such as corporate firms (Barsky, 1999), high-tech start-ups (Hannan, Burton, and Baron, 1996), mutual funds 
(Siggelkow, 2002), top management teams (Roberto, 2003) and FLOSS development groups (Crowston et al., 2006). According to this model, an organization can be divided into two components: the core, made of highly cohesive and interdependent members, and the periphery, composed of actors less densely connected and less involved in the network's ongoing activities (Borgatti and Everett, 1999). As Hannan and colleagues noted, 'coreness means connectedness, elements in the core are linked in complicated webs of relations with each other and with peripheral elements’ (Hannan et al., 1996: 506). Thus core organizational actors are those who play key coordinating roles, which gives them greater relevance and exposure within and beyond the organization, and makes them more central to the organization's interdependent webs of routines and tasks (Humphrey, Morgeson, and Mannor, 2009; Summers, Humphrey, and Ferris, 2012), as compared to peripheral organizational members who have 'less integrative importance’ (Knoke et al., 1996: 23).

Given the higher levels of interdependence of the network core (Borgatti and Everett, 1999; Siggelkow, 2002) and the benefits relational stability provides to managing task interdependence efficiently (Reagans et al., 2005; Harrison et al., 2003), we might expect relational stability to have more impact on organizational performance when it resides in relationships located at the network core, where task interdependence is at its maximum. We therefore posit that relational stability coming from dyads among core organizational members (which we label Core Relational Stability - $\mathrm{RS}_{\mathrm{C}}$ ) will have a stronger positive impact on performance than that emerging from dyads including at least one peripheral actor (Peripheral Relational Stability - RS ). Thus:

HYPOTHESIS 1. Core Relational Stability $\left(R S_{C}\right)$ has a stronger positive effect on organizational performance than Peripheral Relational Stability $\left(R S_{P}\right)$.

\section{Relational stability's marginal effect on organizational performance}

In addition to influencing the strength of the link between relational stability and organizational 
performance, the network location of a stable relationship might also impact its marginal effect. Since the benefits of relational stability derive from learning processes and accumulation of tacit knowledge that facilitate coordination, one would expect such effect to display positive decreasing returns akin to those of learning curves (Epple, Argote, and Devadas, 1991). However, we believe that the marginal returns of relational stability will decrease at a faster rate when they derive from stable dyads between core members (or $\mathrm{RS}_{\mathrm{C}}$ ) than from dyads involving at least one peripheral member (or $\mathrm{RS}_{\mathrm{P}}$ ). Our reasoning is based on two different sets of mechanisms, the first internal and the second external to the organization.

The set of internal mechanisms that warrant diminishing returns to performance for $\mathrm{RS}_{\mathrm{C}}$ is grounded on the same network characteristic that makes $\mathrm{RS}_{\mathrm{C}}$ more relevant than $\mathrm{RS}_{\mathrm{P}}$ : the higher level of interdependence among core members. As discussed, stability promotes the generation of tacit knowledge (Berman et al., 2002), which facilitates coordination of interdependent tasks, thus positively affecting performance (Reagans et al., 2005). However, as core members' activities are those where most of the interdependence resides, higher levels of $\mathrm{RS}_{\mathrm{C}}$ will correspond to a comparatively higher stock of tacit knowledge than in the case of $\mathrm{RS}_{\mathrm{P}}$, making the network core comparatively more susceptible to knowledge ossification than the periphery (Berman et al., 2002). Knowledge ossification is a process via which, over time, a high stock of tacit knowledge becomes less flexible, inhibiting further adaptation and learning (Berman et al., 2002). Thus, while still beneficial for coordination, high levels of $\mathrm{RS}_{\mathrm{C}}$ may lead to rigidity and reduced internal communication, as members need less interaction to coordinate their actions (Katz, 1982). When high levels of $\mathrm{RS}_{\mathrm{C}}$ make collectives too self-referential and inward-looking, such increasingly established routinization limits variation and restricts organizations’ ability to adapt to changing environments, possibly triggering competency traps (Levinthal and March, 1993). Such processes may thus turn core competencies into core rigidities (Argyris, 1999), making high levels of $\mathrm{RS}_{\mathrm{C}}$ increasingly less beneficial, and even 
potentially detrimental, for organizational performance (Berman et al., 2002). This view echoes evidence in the literature against stability's monotonic influence on organizational outcomes (Katz, 1982; Berman et al., 2002). In contrast, the lower level of interdependence of dyads involving at least one peripheral member makes them less vulnerable to knowledge ossification and potential learning rigidity.

The external set of mechanisms justifying the faster decrease of performance returns to $\mathrm{RS}_{\mathrm{C}}$ relates to the effect of relational stability on rivals' strategic responses. In competitive contexts, when facing a highly stable organization, rivals have the opportunity to develop effective competitive responses in order to outperform their opponents (White, 1981; Aime et al., 2010). Three independent mechanisms enable rival organizations to develop such countermeasures. The first is the predictability of a focal organization's actions. An initial lack of response on the part of rivals to a focal organization's successful routine set is generally due to their insufficient knowledge about such routines (Aime et al., 2010). However, if the routine set does not change, it will become more predictable and over time rivals will adjust to it successfully. At high levels relational stability increases predictability by strengthening collective identity: while this facilitates coordination, providing the focal organization with a temporary advantage (Zuckerman, 2008), the ensuing stable role structure enables competitors to understand, anticipate, and thus take advantage of how the focal organization can be expected to respond to different situations (Zuckerman, 2008; Aime et al., 2010). The second mechanism is observability. While predictability allows rivals to adjust successfully to a focal organization's actions, that adjustment is likely to be faster in contexts where rivals can observe directly the focal organization's enactment of its stable routine set, allowing them to develop appropriate competitive responses more easily (White, 1981). As rivals observe a focal organization, the value of the tacit knowledge embedded in its network decreases, since they use their observations to develop increasingly effective 
competitive strategies and tactics (Aime et al., 2010). The third mechanism is exposure. Observation alone is often insufficient to allow rivals to learn enough about a focal firm's routine sets to adapt their strategies successfully, as they may not be able to capture all the nuances of a given routine set without some level of direct exposure, possibly via direct interaction with the focal organization (Berman et al., 2002; Aime et al., 2010). Greater exposure to a stable organization's routine set will afford rivals greater understanding of how it is enacted, allowing them to develop more effective responses (Aime et al., 2010).

The predictability, observability, and exposure of routines performed by stable core dyads are greater than those enacted by dyads located in other parts of the network structure. As core organizational members enact routines more frequently, not only do they become more predictable and observable over time, but rivals may have more opportunities of becoming directly exposed to them, increasing the likelihood of developing effective competitive responses (Aime et al., 2010). In contrast, routines involving at least one member of the organizational network’s periphery are enacted slightly differently and less frequently, reducing their predictability and observability and limiting their exposure to the organization's rivals. This safeguards $\mathrm{RS}_{\mathrm{P}}$ against adaptive competitive responses. Following our reasoning, the increased likelihood of knowledge ossification, and the greater predictability, observability, and exposure, will mean the two types of social capital we have discussed impact performance differently, leading us to posit that:

HYPOTHESIS 2. $R S_{C}$ exhibits positive diminishing performance returns, which decrease at a faster rate than $R S_{P}$.

\section{Comparing the effects of human and social capital on performance in highly}

\section{interdependent settings}

In addition to specifying how network structure might explain differences in the effects of social capital, we aim to highlight how much social capital matters for organizations by 
investigating its relative influence on organizational performance compared to that of human capital. The resource-based view of the firm (Wernerfelt, 1984; Barney, 1991) proposes that a firm's competitive advantage is based on the idiosyncratic nature of its resources, which can be thought as the competitive 'strengths' it uses to ensure positive abnormal performance (Barney, 1991). Such performance can only be sustained over time to the extent that resources are specific to the focal organization, or at least are less likely to be imitated by competitors, making 'imperfect imitability’ a key condition for a resource to generate sustained competitive advantage (Barney, 1991). Thus, looking at whether human or social capital is harder to imitate or substitute should shed light on their relative influence on organizational performance.

Managers consider human capital one of the least imitable - and therefore most strategic resources, an idea that grounds the logic underlying the 'war for talent' and is supported by the resource-based view of the firm (Coff, 1997). This logic implies that a resource that is harder to imitate than human capital should have an even greater impact on organizational performance. Indeed, acquiring social capital on the market is generally more difficult than obtaining human capital. While the latter can be obtained by entering the relevant labor market, or by 'poaching' employees from competitors, acquiring social capital externally involves additional challenges due to its intrinsically relational nature (as a ‘socially complex’ resource; Barney, 1991; Peteraf, 1993). For one, the market for social capital is imperfect, as the amount and quality of information on organizations’ patterns of relations is likely to be very limited, making it harder to forecast, understand, and access than the human capital market. The accumulation of social capital is also likely characterized by time compression diseconomies (Dierickx and Cool, 1989), which further reduce the benefits of acquiring it externally. Even if firms may be able to overcome these limitations by 'lifting out' whole teams from rivals (Groysberg and Abrahams, 2006), managing such operations successfully is much more difficult than simply hiring unrelated talent to increase an organization's stock of human capital. This difficulty of trading 
and acquiring social capital inevitably favors organizations that have already accumulated higher stocks of it. If social capital is hard to acquire externally, organizations' best alternative is to build it up internally - but the characteristics of the accumulation process, such as time compression diseconomies, asset mass efficiency, and causal ambiguity make it very hard to do so (Dierickx and Cool, 1989). For these reasons we argue that social capital is a more valuable source of competitive advantage for organizations than human capital, especially in contexts where the former is of particular relevance for organizations, such as settings characterized by high levels of task interdependence. Thus:

HYPOTHESIS 3. In contexts characterized by high interdependence, social capital has a greater influence than human capital on organizational performance.

\section{METHODS}

\section{Data: The National Basketball Association (NBA)}

We tested our hypotheses using longitudinal data on the membership and performance of American basketball clubs. Several organizational scholars have found sports clubs appropriate contexts in which to investigate organizational phenomena (Aime et al., 2010; Bothner, Kim, and Smith, 2012): they both represent a microcosm of society and mirror the world of work (Keidel, 1987), and so 'can serve as a heuristic to guide researchers in analyzing, and managers in running, organizations' (Wolfe et al., 2005: 184). Sports settings offer scholars several advantages, including accurately measured data, transparency of strategy and processes, and a relatively controlled environment in which clubs compete for the same goals under the same rules (Wolfe et al., 2005; Bothner et al., 2012). Our analyses are based on 45 years of data (1966-2012) from the National Basketball Association (NBA). We statistically modeled the yearly performance of NBA franchises1 between 1976 and 2012, generating a sample of 960 franchise-year observations involving 30 NBA franchises. The year 1976 is generally

\footnotetext{
${ }^{1}$ A sport club operating in the NBA is usually referred to as a 'franchise.'
} 
considered the first year of the 'modern-day' NBA, created after the merger between the original NBA and the American Basketball Association (ABA), a rival league that operated between 1967 and 1975. We extended our data collection back to 1966 - including data from both leagues - to calculate lagged variables, including our indicator for relational stability.

We used data on individual players to calculate our explanatory and control variables. Since our focus was on those players who stayed with a club long enough to have a meaningful impact on its social mechanisms, we restricted our sample by including only players who appeared on a game roster for at least $5 \%$ of the games each team played in a season ${ }^{2}$, which lead to a final sample of 18,900 player-season observations. To ensure correct temporality in our estimation, we lagged all our explanatory and control variables by one year ${ }^{3}$. We also gathered anecdotal evidence in the form of a 60-minute exploratory interview with one of the most successful coaches in international basketball history, which supported both our theorizing and the operationalization of our variables.

\section{Core/periphery structures in the NBA}

Basketball clubs have a clear core/periphery network structure (Wallace, 1988; Bray, Brawley, and Carron, 2002), which makes them an appropriate context in which to test our hypotheses. They present a subset of highly interdependent core players (the primary unit) and a less interdependent group of 'bench' players (the secondary unit), thus displaying characteristic core/periphery structures (Borgatti and Everett, 1999). While a team can field 12 players for each game, only five of them are active on the court at the same time. Thus, coaches build their teams around a smaller set of three to seven players (the core) who play the majority of the game and rotate secondary players (the periphery) on and off the court around them. Figure 1

\footnotetext{
${ }^{2}$ Alternative cut-offs of $10 \%$ and $15 \%$ did not significantly affect our results.

${ }^{3}$ To enhance the generalizability of our results, we tested our hypotheses on a second sample composed by all 57 basketball clubs that played in the Italian Basketball Major League ('Lega Basket Serie A', or simply 'Serie A') over 35 seasons (1975-76 through 2009-10), for a total of 398 club-year observations. The results presented in this paper were largely confirmed by the analyses conducted on the Italian sample. For parsimony, we omitted the latter analyses, which are available from the authors.
} 
illustrates this structural feature among the Boston Celtics’ players during the 2009/10 season.

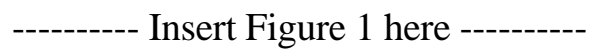

Figure 1 illustrates the structural interdependencies of the team's network. Here, ties represent the total number of minutes each pair of players spent on court together during the 2009/10 season: thicker lines represent higher counts, i.e. more time spent playing alongside each other. A clear structural pattern emerges: one subset of players works together more often, both amongst themselves and with peripheral members, while another subset play less frequently with each other. Hence, while all players face the same fundamental tasks like shooting, dribbling, passing, and defending, their actual roles may be more or less interdependent contingent on their structural position in the team. This intuition is supported by analyzing the network using a core/periphery algorithm to statistically identify members of the network core (Borgatti and Everett, 1999). The players identified by the algorithm as part of the core are represented by triangles in Figure 1, statistically supporting the initial intuitive idea that the core and periphery members in a basketball club are clearly separated.

\section{Core/periphery operationalization}

The fine-grained minute-by-minute data used to construct the network as displayed in Figure 1 is available only after 2005, preventing us from applying Borgatti and Everett’s algorithm to calculate the structural positions of the players in our complete sample. We therefore decided to use average minutes played per game to distinguish between players belonging to either the core or the periphery (a decision validated by the industry expert we interviewed). We performed two analyses to confirm the construct validity of our operationalization. First, we built networks of interdependencies (similar to Figure 1) for the entire NBA between 2006 and 2010, which yielded a total of 120 networks involving 1,952 nodes. We then calculated a measure of network coreness for each player in these networks (Borgatti, Everett, and Freeman, 2002), an indicator generated by Borgatti and Everett’s algorithm (1999) to classify 
network nodes as either belonging to the core or to the periphery. The correlation between network coreness and our chosen measure in this sub-sample was very high $(0.90 ; n=1,952)$, which gave us a reasonable certainty that average minutes played per game was a valid measure for distinguishing between core and peripheral players.

Second, we calculated the structural position (core or periphery) of the 1,952 playeryears that were part of this 2006-2010 sub-sample using Borgatti and Everett's procedure (1999), and then used logistic regression to predict players' structural position $(1=$ core; $0=$ otherwise) based on their average minutes played per game. We used the estimated coefficients to calculate the predicted probabilities of players being members of the network core by different levels of average minutes played per game. As Figure 2 shows, the predicted probability function increases steeply between 24 and 28 minutes played per game (which typically lasts 48 minutes). We therefore decided to consider those players who played on average more than 26 minutes per game over a season as part of the network core.

Sensitivity analyses, conducted by varying this threshold by one minute in either direction revealed no significant changes in the results of our statistical models. We also considered teams' head coaches as part of the core, given their central role both in building the extant routine set and in deciding which routines were to be enacted.

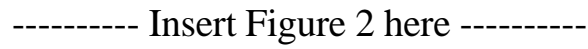

\section{Dependent variable}

Organizational performance. We measured our dependent variable as the percentage of games won during the regular season, which is consistent with how previous studies have accounted for success in similar contexts (Allen, Panian, and Lotz, 1979; Bloom, 1999; Pfeffer and Davis-Blake, 1986) ${ }^{4}$. As percentage of games won is a continuous variable bounded between 0

\footnotetext{
${ }^{4}$ In the NBA teams do not face all their opponents an equal number of times. This means that some teams encounter tougher competition. To control for this potential bias, we ran additional analyses using an alternative measure of performance called the Simple Rating System (SRS; Kubatko, 2008). These robustness checks, which are available from the authors, did not show substantially different results from those reported here.
} 
and 1, which could be problematic when applying regression analysis, we decided to transform our dependent variable using a logit link function (Greene, 2008). Robustness checks using a non-transformed version of our DV yielded the same results.

While we believe that the winning record is a valid indicator of performance, a counter argument might be that managers are tempted to hire superstars to widen their club’s fan base to maximize ticket sales and merchandising revenues, which might make the winning record a secondary goal. Therefore, when testing the relative impact of human capital vs. social capital, we used stadium attendance - the total number of stadium seats occupied for each franchise's home games in each season - as an additional measure of performance.

\section{Independent variables}

Social capital: Relational stability core and periphery $\left(R S_{C}\right.$ and $\left.R S_{P}\right)$. Consistent with previous research showing that shared experience is accumulated at the dyadic level (Reagans et al., 2005; Perretti and Negro, 2006), we assessed a club’s RS $_{C}$ as the number of stable dyads present in the team core over time. Hence we calculated $\mathrm{RS}_{\mathrm{C}}$ by counting, for each pair of core members - players with an average of more than 26 minutes per game over the season, plus the coach - the number of seasons they had played together over the previous ten years ${ }^{5}$. It is important to note that we also considered players' past common experience at clubs where they had played together previously. Thus, an imaginary Club Alpha which has three core members (A, B and C) who have played together before - A and B for the last three seasons, with C joining only one year ago - would have a $\mathrm{RS}_{\mathrm{C}}$ value of $5(\mathrm{~A}-\mathrm{B}=3, \mathrm{~A}-\mathrm{C}=1$, and $\mathrm{B}-\mathrm{C}=1)$. But if B and C had previously played together for Club Beta for one season five years ago we should increase the B-C score to 2, raising Club Alpha's $\mathrm{RS}_{\mathrm{C}}$ value to 6 . We obtained $\mathrm{RS}_{\mathrm{P}}$ following the same logic used for $\mathrm{RS}_{\mathrm{C}}$, except that in this case we considered any possible dyad that

\footnotetext{
${ }^{5}$ Since we would expect older shared experiences to have less impact than newer ones on the ability to implement current routine sets, as a robustness check we tried to discounted the impact of a stable dyad by different rates for every season prior to the past one. All our results were robust to this different specification of our social capital measure.
} 
involved at least one peripheral player (i.e., dyads composed of one core and one peripheral player, or of two peripheral players). We also used a common relational stability measure relational stability total $\left(R S_{T O T}\right)$ - to account for the overall effect of relational stability, irrespective of its network location. In each case, we calculated clubs' relational stability scores as accumulated at the beginning of each season (i.e., up to and including the previous one). Human capital. The NBA data archive contains detailed statistics for every player that has played in league games, which can be integrated in single indices to summarize players’ performance: of these, most experts consider the Player Efficiency Rating (PER) as the most reliable measure of individual performance (Kubatko et al., 2007). The PER is calculated not only by accurately weighting multiple individual statistics (including points scored, missed shots, rebounds, steals, blocks, turnovers and assists), but also by standardizing for minutes played and the team 'paces' that result from more offensive or defensive team strategies, resulting in an indicator that most closely captures individual players' talent, with no inflation due to team and coaching strategies. To account for each team's human capital potential, we considered the players available to each team at the beginning of each season, and then averaged their PER for the previous season (t-1), which gave us an overall picture of the human capital potential available to each club at the start of each season.

We performed two robustness checks to confirm the construct validity of PER as a human capital indicator. Since a fundamental assumption behind human capital is its relative stability over time (Becker, 1964), we checked whether our measure captured that stability by calculating the year-to-year PER correlation: the value we obtained (0.65) seemed to confirm the validity of this assumption. Another assumption behind human capital theories is that the job market offers higher monetary rewards to more talented individuals: again, a correlation of 0.42 between salary and previous year PER seems to indicate the measure's reliability. 
Previous performance data was by definition missing for players in their first season in the league (known as 'rookies'). The NBA job market is highly regulated, with players bargaining their contracts through their union by negotiating a collective agreement (CBA) with the franchise owners. The entry of new players into the league's franchises is also constrained by a draft system. Thus, the NBA can be considered as an almost closed system: between 1976 and 2012, only 2,544 of the 15,549 player-season observations (16\%) involved rookies. Given these factors, we handled rookies’ prior performance data in two separate ways: first, by excluding them altogether from the human capital calculations, and second, by using their current year efficiency as a proxy for their talent. As these two choices did not yield significantly different results, we chose to present the latter as it provided slightly better model fit.

\section{Control variables}

Individual experience. Following Reagans and his colleagues (Reagans et al., 2005), we designed three variables to control for the effect of individual players' experience. We included teams' players' average age to account for potential reduced physical fitness and/or motivation that might negatively affect older players’ performance. We also controlled for the players'

average tenure with the club (i.e., the average number of seasons team members had played for the focal club), to account for how players working for the same team over several seasons might develop club-specific tacit knowledge. Becoming familiar with the clubs' training structures and fans, and ultimately with the city where they played could all be important factors affecting both players' performance and their decision to stay with the club. Finally, we included the players'average experience in the league in our models as an indicator of leaguespecific experience, as the average number of seasons team members had played in the league. Organizational experience. This variable expresses the league-specific experience embedded in each club, and was measured as the number of years each club had been in the NBA before the focal season. In addition to the level of experience with the specific context, this variable also 
acts as a proxy for a club’s status and tradition within the league, which, it could be argued, might significantly correlate with our explanatory variables - higher status clubs might find it easier to retain their top players and attract better 'free agent' players.

Coaching variables. As superior coaching skills might significantly impact clubs' chances of winning games (Pfeffer and Davis-Blake, 1986; Berman et al., 2002) and could also be correlated with our explanatory measures, we included three separate variables in our models to control for these potential issues. First, more experience with the club can lead coaches to better understand players' strengths and weaknesses as well as which strategies they could expect to implement successfully. To capture this effect, we included coach's tenure with the club as a variable measuring the number of seasons a coach had been with the club. Second, since having a better coach could lead players to stay with the team longer, we included each coach's overall record in our models (coach's league record), computed as the percentage of total career wins over total games coached in their NBA careers. Third, since a coach with a longer Major League career has more experience to draw on when deciding which strategies to implement on the court, we included the variable coach's experience in the league measured as the total number of seasons each individual had coached in the NBA.

Team size. Our exploratory interview suggested that we could expect bigger teams to be more difficult to manage, which might make them less likely to perform well. To control for team size we used a variable called number of players, calculated as the total number of players who played in at least $5 \%$ of the total games in each season. Since team size will expectedly be highly correlated with our relational stability indicators, we broke this measure down into two different variables - core size and periphery size - to fully account for their potential effects. Number of newcomers. A low relational stability value for a club might be due to a high turnover of team players, so to capture this effect we controlled for turnover by including the overall number of newcomers in our models. As the increased cognitive variety involved in 
high player turnover would tend to counter knowledge ossification (Berman et al., 2002), including this variable also controls for the positive effect newcomers might have on performance, whether or not they had previously played with extant team players.

Salary structures. The structure and size of employee contracts might confound the effect of some of our explanatory variables, especially relational stability. Higher payrolls may allow teams to retain better players longer, as well as motivate them to perform better. Thus, total team payroll was included as a control, in the form of standard scores calculated on an annual basis. Unfortunately, salary data was not available for our full sample, so this control variable was only included on a restricted sub-sample $(n=707)$ in one of our regression models in order to maximize sample size in rest of our analyses.

Team and year indicator variables. Despite our best efforts to envisage and control for potential alternative explanations, there could be several others factors which might interfere with predicting team success. For example, teams based in major cities are more likely to have bigger arenas, broader supporter bases, and to gain greater national and local media attention, all of which could give them greater earning power, and thus the possibility of retaining players for longer periods. Basketball is also more embedded in the local culture of some geographical areas than others, so levels of team support will differ. Finally, the financial resources made available by a team's owners and sponsors will no doubt also contribute to further differentiating clubs' financial capabilities. Since reliable data on local basketball culture, revenues, and profitability were not consistently available, we included a club-level fixed effects variable in our regression models to capture any heterogeneity unaccounted for by other control variables, as well as indicator year variables to account for time-based fixed effects.

\section{Estimation model}

We exploited the longitudinal nature of our data fully by employing regression procedures designed for panel data. A significant Hausman test result ( $\mathrm{p}<0.001)$ indicated that random- 
effect coefficients were not reliable, confirming our preference for fixed-effects estimators to control for unobserved heterogeneity across panels (Greene, 2008). Using the test proposed by Greene (2008) we identified the presence of group-wise heteroskedasticity in the residuals of our fixed-effect models $(\mathrm{p}<0.001)$. We used Huber-White estimators of variance (White, 1980) and clustered the robust standard errors at the club-level to correct for this potential bias. To further ensure the robustness of our results, we also tested for the presence of first-order serial correlation in linear panel-data models, as discussed by Wooldridge (2010). Since the results were significant $(\mathrm{p}<0.001)$, indicating the potential presence of autocorrelation in our data, we re-estimated some of our models using a Generalized Least Squares procedure (GLS), a generalization of OLS that enables controlling for panel-specific first-order serial autocorrelation and heteroskedasticity across panels (Greene, 2008; Castilla, 2007).

\section{RESULTS}

Table 1 reports the descriptive statistics and bivariate correlations for our variables, providing initial evidence for our theorizing. As expected, most control variables - such as human capital, players' experience with the organization, organizational experience, and coach record - are positively correlated with organizations' winning records. The positive correlation coefficients between our indexes of relational stability and organizational performance also seem to support Hypothesis 1 and provide initial support for Hypothesis 2, whose curvilinear assumption requires multivariate regression models to be fully tested.

Insert Table 1 here

Table 2 presents the results of our multivariate regression analysis. Model 1 includes all the control variables and Models 2 through 6 include the explanatory variables used to test our hypotheses. All the models converge and are statistically significant $(p<0.001)$.

Control variables. Model 1 shows that several control variables are statistically significant in 
the expected directions, with most relationships holding across all the models. Larger teams seem to perform worse $(p<0.001)$, but while we expected the same to be true of older teams, the relationship between age and performance was not statistically significant. Moreover, individual experience in the league and performance are positively related, albeit with only partial statistical reliability $(\mathrm{p}<0.1)$. As expected, organizational experience is positively related to performance $(p<0.01)$, and its negative quadratic term displays diminishing returns $(\mathrm{p}<0.001)$. Coaching ability also clearly matters, as coaches’ past winning records are positively related to performance $(p<0.001)$. Most importantly, all our models support the positive role of human capital for performance $(p<0.001)$.

Hypotheses 1 and 2. Models 2 to 5 tested Hypotheses 1 and 2. Model 2 introduces our first indicator of social capital, relational stability total $\left(R S_{T O T}\right)$, a variable that captures the dyadic stability of teams' networks without differentiating for the network position of the stable dyads. The coefficient of $\mathrm{RS}_{\mathrm{TOT}}$ is positive and statistically significant $(\mathrm{p}<0.001)$. Moreover, the negative direction and statistical significance of $\mathrm{RS}_{\mathrm{TOT}}$ quadratic term $(\mathrm{p}<0.01)$ - included in Model 3 - proves that (consistent with previous theorizations) relational stability displays diminishing returns when considered as a whole (Epple et al., 1991).

Model 4 introduces the linear terms for relational stability core $\left(\mathrm{RS}_{\mathrm{C}}\right)$ and relational stability periphery $\left(\mathrm{RS}_{\mathrm{P}}\right)$, both of which show positive and statistically significant coefficients $(p<0.01)$. A comparative F-test between the two coefficients provides initial statistical support for $\mathrm{H} 1$, showing that the linear coefficient for $\mathrm{RS}_{\mathrm{C}}$ is greater than that for $\mathrm{RS}_{\mathrm{P}}(\mathrm{p}<0.001)$. We then add the mean-centered quadratic terms for $\mathrm{RS}_{\mathrm{C}}$ and $\mathrm{RS}_{\mathrm{P}}$ in Model 5, where the positive and statistically significant $(p<0.001)$ coefficient for $\mathrm{RS}_{\mathrm{C}}$ and the negative and statistically significant $(p<0.001)$ coefficient for its squared term shows how stability of relations between core members displays diminishing returns to organizational performance. In Model 4, the significant $(p<0.001)$ and positive coefficient for relational stability periphery $\left(\mathrm{RS}_{\mathrm{P}}\right)$ and the 
lack of support for its quadratic coefficient ( $\mathrm{p}>0.05$ ), suggests that, in contrast to $\mathrm{RS}_{\mathrm{C}}, \mathrm{RS}_{\mathrm{P}}$ 's relationship to performance is linear ${ }^{6}$. While this provides initial support for H2, Figure 3a investigates the relationships between these two forms of relational stability and organizational performance further.

Insert Figures 3a and 3b here

Figure 3a illustrates the estimated functions that link our two relational stability indicators to organizational performance in a graph with standardized axes. $\mathrm{RS}_{\mathrm{C}}$ exhibits a stronger effect on performance but also diminishing returns, given the curvilinear and concave trajectory of the function and its evident reduction in slope. In contrast, $\mathrm{RS}_{\mathrm{P}}$ displays a linear relationship to performance with constant marginal returns. Figure 3a and Model 4 provide graphical and statistical evidence to support Hypothesis 2, which predicted $\mathrm{RS}_{\mathrm{C}}$ would have decreasing marginal returns compared to $\mathrm{RS}_{\mathrm{p}}$.

The quadratic nature of $\mathrm{RS}_{\mathrm{C}}$ requires further analysis to test $\mathrm{H} 1$ fully. In fact, given that the slope of the curve changes at different levels of $\mathrm{RS}_{\mathrm{C}}$, we needed to conduct a comparison between the coefficients of $\mathrm{RS}_{\mathrm{C}}$ and $\mathrm{RS}_{\mathrm{P}}$ at multiple points on the curve. Figure $3 \mathrm{~b}$ plots the values of the coefficients for $\mathrm{RS}_{\mathrm{C}}$ and $\mathrm{RS}_{\mathrm{P}}$ over their full data range, together with their confidence intervals. The estimated coefficient for $\mathrm{RS}_{\mathrm{C}}$ is greater than that for $\mathrm{RS}_{\mathrm{P}}$ between -1.5 and +2 standard deviations $(\mathrm{SD})$, and with statistical reliability $(\mathrm{p}<0.05)$ between -1.5 and +1

SD. $\mathrm{H} 1$ is thus supported with statistical certainty within the latter data range.

As players' salary data were only partially available, we tested their influence in a separate model (Model 6), which thus features a subsample of our data $(\mathrm{n}=707)$. As expected, having a higher payroll seems to be positively related to organizational performance $(p<0.1)$, but clubs’ payroll size also displays diminishing returns, as shown by the negative and statistically

\footnotetext{
${ }^{6}$ To fully account for the correlations between our control and explanatory variables, we ran an additional analysis including all our control variables split into their core and periphery components, as well as their respective quadratic terms: our main results were robust to this additional specification.
} 
significant $(p<0.05)$ quadratic effect. The inclusion of our salary indicator in this model did not affect the significance of our other findings. Model 7 re-estimates the complete Model 5 using a different estimation technique - a Generalized Least Squares procedure (GLS) - which allows us to control for the first order autocorrelation of our residuals (Greene, 2008). As reported in Table 2, Model 7, which includes a panel-specific AR1 autocorrelation structure, confirms the results obtained by the previous estimations.

Hypothesis 3. We employed GLS procedures to test H3 in Models 8 and 9, where we compare the standardized coefficients of human capital and social capital (using $\mathrm{RS}_{\mathrm{TOT}}$ ). Model 8 is simply the GLS-estimated version of Model 3, and similarly displays a quadratic effect for $\mathrm{RS}_{\mathrm{TOT}}$. A comparative chi2-test between the human and social capital coefficients reveals no statistical difference in the magnitude of their effects at mean levels $(p>0.05)$, thus not providing support for H3, which posited a stronger influence of social capital on organizational performance. Model 9 uses a different operationalization of our dependent variable (stadium attendance) to compare the effects of human and social capital. Even in this case, both our explanatory variables show positive coefficients $(\mathrm{p}<0.001)$, but yet again are not statistically different from each other at the 95\% level ( $p>0.05)$. In summary, our estimations do not provide supporting evidence for $\mathrm{H} 3$, as the effects of social and human capital are statistically indistinguishable.

\section{Regression diagnostics and robustness tests}

We conducted regression diagnostics on the full models to consider potential violations of regression assumptions: residuals appeared to be normally distributed on a quantile-quantile plot, and the low VIFs we found for our independent variables (mean VIF: 3.17) seemed to exclude severe multi-collinearity issues. We also tested for the presence of influential outliers by estimating our models with a robust regression procedure (Wooldridge, 2010) that was robust to their presence: the results fully confirmed those reported here. 
Endogeneity and reverse causality. As a team's composition might be influenced by its past performance (following the well-known folk heuristic ‘never change a winning team') we acknowledge that endogeneity could potentially affect our results. In econometric terms, our dependent variable is likely to be dynamic, depending on its lagged realizations, and our independent variables could be correlated with past realizations of the error term. Employing Arellano-Bond (AB) dynamic panel estimators (Arellano and Bond, 1991) helped to alleviate our endogeneity concerns, and allowed us to include a lagged dependent variable to control for reverse causality (Greene, 2008) while avoiding dynamic panel bias (Roodman, 2009). $\mathrm{AB}$ estimators also removed unobserved heterogeneity by instrumenting endogenous repressors with their past realizations. ${ }^{7}$ Table 3 reports the results of our analysis using AB estimators (Model 10). We transformed our data using orthogonal deviations (Arellano and Bover, 1995) because of the presence of gaps in our panel data (Roodman, 2009), and specified the indicators for human capital, social capital, coach tenure with the team, number of newcomers and players' experience with the team as endogenous. The coefficients reported show that this additional estimation substantially confirms our prior results. A nonsignificant ( $p>0.05)$ Sargan test (Roodman, 2009) suggests our estimates were unlikely to be affected by over-identification, proving the validity of our instruments.

Curvilinearity test. We ran a moderated curvilinearity test (Cohen et al., 2003) to seek additional support for H2. We wanted to prove that the degree of curvilinearity (and hence, the diminishing returns) of the relationship between relational stability and organizational performance increases as stability becomes increasingly concentrated among core team members. We estimated a regression model using our single measure for overall team stability $\left(\mathrm{RS}_{\mathrm{TOT}}\right)$ and its mean-centered quadratic term $\left(\mathrm{RS}_{\mathrm{TOT}}{ }^{2}\right)$, and then introduced in the model a

\footnotetext{
${ }^{7}$ A significant Arellano-Bond test $(\mathrm{p}<0.001)$ proved the presence of serial autocorrelation of order 1 in our data, which ruled out $\mathrm{t}-2$ realizations of our dependent variable from the instrument set and $\mathrm{t}-1$ realizations from our models (Roodman, 2009). We also restricted the instrument set to $t-3$, to keep the overall number of instruments under control, as a large number of instruments may indeed bias our estimates (Roodman, 2009).
} 
measure of coreness (Coreness ${ }_{\mathrm{RS}}$ ) by dividing $\mathrm{RS}_{\mathrm{C}}$ by $\mathrm{RS}_{\mathrm{TOT}}$, so creating an index that represented the percentage of $\mathrm{RS}_{\mathrm{TOT}}$ concentrated in the team core. Finally, we created interaction terms between Coreness ${ }_{\mathrm{RS}}$ and both $\mathrm{RS}_{\mathrm{TOT}}$ and $\mathrm{RS}_{\mathrm{TOT}}{ }^{2}$, and statistically tested their interactions. For better interpretation, these results are graphically displayed by the regression surface in Figure 4, which shows the change of the effect of relational stability (x-axis) on team performance (z-axis) contingent on the variation in coreness of such stability (y-axis). Insert Figure 4 here

These results suggest that, at low levels of coreness (closer to the viewer), the marginal effect of relational stability on performance is approximately linear, but when relational stability is concentrated in the network core (farther away from the viewer), the functional form describing its effect on performance becomes parabolic. Taken together, these findings provide additional evidence for our hypotheses.

\section{DISCUSSION AND CONCLUSION}

\section{Theoretical contributions}

We contribute to the advancement of the literature on social capital by specifying the strength and functional shape of its relationship with organizational performance. We do so by demonstrating how the impact of relational stability on organizational performance depends on the structural position of the members participating in stable dyads. Specifically, the impact of social capital accumulated among core members is stronger than that deriving from dyads that include at least one peripheral member, yet it is subject to diminishing returns. This finding also helps to reconcile the current mixed evidence found in the literature on shared experience and team familiarity, particularly in relation to the connection between stability and organizational performance. Although most management literature agrees on the beneficial role of stability and common experience in teams and organizations, some scholars have found evidence for a strictly linear relationship between stability and performance 
(Reagans et al., 2005), while others have found diminishing returns (Berman et al., 2002) or even inverted U-shaped effects (Katz, 1982). Our analysis proposes that such confusion might stem from assuming all organizational members to be structurally equal, and shows how the assumption of structural equality might lead scholars to ignore variations in interdependence across internal network structures. This overlooks the possibility that the returns of stability to performance may differ in magnitude and functional form when they emanate from different parts of the network. By highlighting the role of networks' structural features in accounting for the performance implications of social capital, we also contribute to the current research specifying the micro-determinants of the integration of resources within organizations, consistent with the view that 'not only does the level of a resource matter, but so too does its structure within the team' (Gardner et al., 2012: 1001). As our setting is populated by organizations which display a fairly definite core/periphery structure, it was relatively easy for us to differentiate between parts of the network characterized by stark differences in the degree of interdependence and observability. This may not be true in all organizational settings. For instance, organizational networks may be defined by a homogeneous degree of interdependence across their structure, may be more or less observable, or might also display multiple areas of high interdependence. Future research should consider the validity of our findings across these various scope conditions.

When comparing the effects on performance of human and social capital, our empirical evidence does not substantiate our theoretical argument, based on the resource-based view of the firm (Barney, 1991). Since we considered human capital as a resource that is easier to acquire externally than social capital, we expected social capital to yield higher performance returns than human capital (Peteraf, 1993). However, our data shows that the effects of the two types of capital are statistically indistinguishable. Our findings seem to question one of the fundamental premises of the resource-based view of the firm: that idiosyncratic resources may 
not be necessarily more valuable than more transferable ones (Barney, 1991), and might instead carry some drawbacks. We speculate that in high visibility conditions, the deployment of idiosyncratic resources may make the focal organization more predictable and more susceptible to competitors' timely strategic countermeasures, in part limiting their potential strategic value. Another factor might be linked to the settings' high level of interdependence: while relational stability provides a coordination advantage in these settings, at the same time it might also impede quick adaptation if and when change becomes necessary, thus limiting the value of this type of social capital. We believe that exploring the limits of such internally-accumulated resources might represent an important avenue for future studies in the resource-based tradition.

We should also point out that our investigation of the link between social capital and performance is likely to provide a conservative assessment of its value for organizations, for at least two reasons. First, by focusing on relational stability we only considered the role played on performance by internal social capital - future studies which include external social capital as well might indeed show social capital as having a greater impact on organizational performance than human capital in highly interactive settings. Second, the impact of relational stability on organizations is likely to be much broader than we have been able to investigate, as social capital is likely to affect many other important organizational outcomes in addition to performance (Dess and Shaw, 2001).

\section{Implications for practice}

While we did not find support for our third hypothesis, the fact that the effects on performance of human and social capital are not statistically distinguishable carries relevant practical ramifications, challenging the traditional belief that emphasizes the value of skills over that of relationships. Our results suggest that in addition to maximizing the organizational stock of individual talent, paying more attention to social capital might be a worthwhile parallel practice in hiring and retaining employees which could enable organizations and teams to reap fuller 
benefits from their existing network structures (Reagans et al., 2004). Hiring the most talented individuals might not be the best solution if it comes at the expense of sacrificing stability, as the advantages associated with the new talent might be offset by social capital losses. A more balanced solution might be to pursue younger individuals with talent potential who will grow together within the company, thus benefitting from both the immediate advantage afforded by talent and the longer term benefits of developing stable relationships within the company.

We suggest that managers should focus on creating the conditions for structural stability by trusting employees, even if they are not immediately successful, giving them time to know and adjust to each other's tasks and routines, and stimulating the creation of a safety net to minimize and tolerate short-term inefficiencies generated by temporary errors and mistakes. Our findings represent additional evidence against the widespread practice of hiring temporary workers to maximize cost flexibility (Vough, Broschak, and Northcraft, 2005). While it is true that offering short-term non-guaranteed contracts allows managers to adjust more quickly to demand fluctuations, the practice also undermines the accumulation of social capital, an important source of competitive advantage.

\section{Limitations and future research}

When evaluating the results of this study, we must alert the reader to its limitations. Despite the advantages of studying sport teams, this type of organizations does not represent the whole spectrum of organizational activities. While basketball clubs' characteristics might match those of most production or service-oriented organizations, the applicability of our findings may differ in other contexts, such as organizations dealing primarily with creative tasks, although research has shown that past common experience is also critical for creative outputs (Taylor and Greve, 2006). Future research could also look at the different nature of the routines behind different types of organizational tasks, and associate them with the beneficial and/or detrimental effects of social capital in stable or changing conditions. 
The two mechanisms that we have identified regarding relational stability are predicated on the emergence of knowledge ossification and the presence of rivals that may take advantage of situations of high predictability, observability, and exposure to an organization's routine set. Future studies should investigate to what extent our results hold in contexts where knowledge ossification is less of a concern or in non-competitive settings. Finally, we have assumed that relations between individuals are not negative, so that shared experience among current organizational members (relational stability) can impact organizational performance positively. While this might seem a strong assumption, what makes it relatively robust is that, especially in sports club, negative ties tend to be broken off, either by the parties involved or by management. Moreover, high levels of task interdependence and network density makes negative relationships less likely to emerge in the context we analyzed (Labianca and Brass, 2006). Thus, we suggest that positive (or at least, non-negative) ties self-select and tend to be those that are more stable over time. While we agree that negative relations are significantly related to organizational outcomes (Labianca and Brass, 2006), such considerations and the longitudinal nature of our data make us confident about the robustness of our findings.

By looking at the interplay of human and social capital, this study has offered a more complete theoretical framework of the processes that explain organizational performance, highlighting where and how social capital is important. Understanding the role relational resources play in linking stability to outcomes might help managers re-think the 'war for talent' by re-evaluating the role of social capital in hiring and retaining practices, which may lead to better performing organizations. 


\section{REFERENCES}

Aime F, Johnson S, Ridge JW, Hill AD. 2010. The routine may be stable but the advantage is not: Competitive implications of key employee mobility. Strategic Management Journal 31(1): 75-87.

Allen MP, Panian SK, Lotz RE. 1979. Managerial succession and organizational performance: A recalcitrant problem revisited. Administrative Science Quarterly 24(2): 167-180.

Arellano M, Bond SR. 1991. Some tests of specification for panel data: Monte Carlo evidence and an application to employment equations. Review of Economic Studies 58(2): 277-297.

Arellano M, Bover O. 1995. Another look at the instrumental variables estimation of error components models. Journal of Econometrics 68(1) 29-51.

Argyris C. 1999. Tacit knowledge and management. In Tacit Knowledge in Professional Practice, Sternberg RS, Horvath JA (eds). Erlbaum: Mahwah, NJ; 123-140.

Barney J. 1991. Firm resources and sustained competitive advantage. Journal of Management 17(1): 99-120.

Barsky NP. 1999. A core/periphery structure in a corporate budgeting process. Connections 22(2): 22-29.

Becker GS. 1964. Human Capital. National Bureau of Economic Research: New York.

Berman SL, Down J, Hill CWL. 2002. Tacit knowledge as a source of competitive advantage in the National Basketball Association. Academy of Management Journal 45(1): 13-31.

Bloom, M. 1999. The performance effects of pay dispersion on individuals and organizations. Academy of Management Journal 42(1): 25-40.

Borgatti SP, Everett MG, Freeman LC. 2002. UCINET for Windows: Software for Social Network Analysis. Analytic Technologies: Needham, MA.

Borgatti SP, Everett MG. 1999. Models of core/periphery structures. Social Networks 21(4): 375-395.

Bothner MS, Kim T, Smith EB. 2012. How does status affect performance? Status as an asset vs. status as a liability in the PGA and NASCAR. Organization Science 23(2): 416-433.

Brass DJ. 1984. Being in the right place: A structural analysis of individual influence in an organization. Administrative Science Quarterly 29(4): 518-539.

Bray SR, Brawley LR, Carron AV. 2002. Efficacy for interdependent role functions: Evidence from the sport domain. Small Group Research 33(6): 644-666.

Castilla EJ. 2007. Dynamic Analysis in the Social Sciences. Elsevier, Academic Press: Oxford (UK).

Cattani G, Ferriani S. 2008. A core/periphery perspective on individual creative performance: Social networks and cinematic achievements in the Hollywood film industry. Organization Science 19(6): 824-844.

Coff RW. 1997. Human assets and management dilemmas: Coping with hazards on the road to resource-based theory. Academy of Management Review 22(2): 374-402.

Cohen J, Cohen P, West SG, Aiken LS. 2003. Applied Multiple Regression/Correlation Analysis for the Behavioral Sciences. Erlbaum: Mahwah, NJ.

Cohen SG, Bailey DE. 1997. What makes teams work: Group effectiveness research from the shop floor to the executive suite. Journal of Management 23(3): 239-290.

Coleman J. 1988. Social capital in the creation of human capital. American Journal of Sociology 94(Supplement): S95-S120.

Crowston K, Wei K, Li Q, Howison J. 2006. Core and periphery in Free/Libre and Open Source Software team communications. Proceedings of the $39^{\text {th }}$ Annual Hawaii International Conference on System Science 6: 118A. 
Cummings J, Cross R. 2003. Structural properties of work groups and their consequences for performance. Social Networks 25(3): 197-210.

Cummings J, Higgins MC. 2006. Relational instability at the network core: Support dynamics in developmental networks. Social Networks 28(1): 38-55.

Dess GG, Shaw JD. 2001. Voluntary turnover, social capital, and organizational performance. Academy of Management Review 26(3): 446-456.

Dierickx I, Cool K. 1989. Asset stock accumulation and sustainability of competitive advantage. Management Science 35(12): 1504-1511.

Epple D, Argote L, Devadas R. Organizational learning Curves: A method for investigating intra-plant transfer of knowledge acquired through learning by doing. Organization Science 2(1): 58-70.

Espinosa JA, Slaughter SA, Kraut RE, Herbsleb JD. 2007. Familiarity, complexity, and team performance in geographically distributed software development. Organization Science 18(4): 613-630.

Gardner HK, Gino F, Staats BR. 2012. Dynamically integrating knowledge in teams: Transforming resources into performance. Academy of Management Journal 55(4): 9981022.

Gardner TM. 2002. In the trenches at the talent wars: Competitive interaction for scarce human resources. Human Resource Management 41(2): 225-237.

Gnyawali DR, Madhavan R. 2001. Cooperative networks and competitive dynamics: A structural embeddedness perspective. Academy of Management Review 26(3): 431-445.

Goodman PS, Leyden DP. 1991. Familiarity and group productivity. Journal of Applied Psychology 76(4): 578-586.

Greene W. 2008. Econometric Analysis. Pearson-Prentice Hall: Upper Saddle River, NJ.

Groysberg B, Abrahams R. 2006. Lift outs: How to acquire a high-functioning team. Harvard Business Review 84(12): 133-140.

Groysberg B, Lee L-E, Nanda A. 2008. Can they take it with them? The portability of star knowledge workers' performance. Management Science 54(7): 1213-1230.

Hannan MT, Burton MD, Baron JN. 1996. Inertia and change in the early years: Employment relations in young, high technology firms. Industrial and Corporate Change 5(2): 503536.

Harrison DA, Mohammed S, McGrath JE, Florey AT, Vanderstoep S. 2003. Time matters in team task performance: Effects of member familiarity, entrainment, and task discontinuity on speed and quality. Personnel Psychology 56(3): 633-669.

Huckman RS, Staats BR, Upton DM. 2009. Team familiarity, role experience, and performance: Evidence from Indian software services. Management Science 55(1): 85100.

Humphrey SE, Morgeson FP, Mannor MJ. 2009. Developing a theory of the strategic core of teams: A role composition model of team performance. Journal of Applied Psychology 94(1): 48-61.

Jones C, Hesterly WS, Borgatti SP. 1997. A general theory of network governance: Exchange conditions and social mechanisms. Academy of Management Review 22(4): 911-945.

Katz N. 2001. Sports teams as a model for workplace teams: Lessons and liabilities. Academy of Management Executive 15(3): 56-67.

Katz R. 1982. The effects of group longevity on project communication and performance. Administrative Science Quarterly 27(1): 81-104.

Keidel RW. 1987. Team sports models as a generic organizational framework. Human Relations 40(9): 591-612.

Knoke D, Pappi FU, Broadbent J, Tsujinala Y. 1996. Comparing Policy Networks: Labor Politics in the U.S., Germany, and Japan. Cambridge University Press: Cambridge (UK). 
Krackhardt D. 1992. The strength of strong ties: The importance of philos in organizations. In Networks and Organizations: Structure, Form, and Action, Nohria N, Eccles G (eds). Harvard Business School Press: Boston, MA; 216-239.

Kubatko J, 2008. The Simple Rating System. From Baskteball-Reference.com. Retrieved on Nov. 11, 2011 from http://www.basketball-reference.com/blog/?p=39.

Kubatko J, Oliver D, Pelton K, Rosenbaum DT. 2007. A starting point for analyzing basketball statistics. Journal of Quantitative Analysis in Sports 3(3): 1-22.

Labianca G, Brass DJ. 2006. Exploring the social ledger: Negative relationships and negative asymmetry in social networks in organizations. Academy of Management Review 31(3): 596-614.

Leana CR, Van Buren HJ. 1999. Organizational social capital and employment practices. Academy of Management Review 24(3): 538-555.

Levinthal DA, March JG. 1993. The myopia of learning. Strategic Management Journal 14(S2): 95-112.

McEvily B, Jaffee J, Tortoriello M. 2012. Not all bridging ties are equal: Network imprinting and firm growth in the Nashville legal industry, 1933-1978. Organization Science 23(2): 547-563.

Mohammed S, Ferzandi L, Hamilton K. 2010. Metaphor no more: A 15-year review of the team mental model construct. Journal of Management 36(4): 876-910.

Payne GT, Moore CB, Griffis SE, Autry CW. 2011. Multilevel challenges and opportunities in social capital research. Journal of Management 37(2): 491-520.

Perretti F, Negro G. 2006. Filling empty seats: How status and organizational hierarchies affect exploration versus exploitation in team design. Academy of Management Journal 49(4): 759-777.

Peteraf MA. 1993. The cornerstones of competitive advantage: A resource-based view. Strategic Management Journal 14(3): 179-191.

Pfeffer J, Davis-Blake A. 1986. Administrative succession and organizational performance: How administrator experience mediates the succession effect. Academy of Management Journal 29(1): 72-83.

Pfeffer J, Sutton RI. 2006. Evidence-based management. Harvard Business Review 84(1): 62-74.

Pfeffer J. 2001. Fighting the war for talent is hazardous to your organization's health. Organizational Dynamics 29(4): 248-259.

Reagans R, Argote L, Brooks D. 2005. Individual experience and experience working together: Predicting learning rates from knowing who knows what and knowing how to work together. Management Science 51(6): 869-881.

Reagans R, Zuckerman E, McEvily B. 2004. How to make the team: Social networks vs. demography as criteria for designing effective teams. Administrative Science Quarterly 49(1): 101-133.

Ren Y, Argote L. 2011. Transactive memory systems 1985-2010: An integrative framework of key dimensions, antecedents, and consequences. Academy of Management Annals 5(1): 189-229.

Roberto MA. 2003. The stable core and dynamic periphery in top management teams. Management Decision 41(2): 120-131.

Roodman D. 2009. How to do Xtabond2: An introduction to difference and system GMM in Stata. Stata Journal 9(1): 86-136.

Siggelkow N. 2002. Evolution toward fit. Administrative Science Quarterly 47(1): 125-159.

Solow D, Vairaktarakis G, Piderit SK, Tsai M. 2002. Managerial insights into the effects of interactions on replacing members of a team. Management Science 48(8): 1060-1073. 
Somaya D, Williamson IO, Lorinkova N. 2008. Gone but not lost: The different performance impacts of employee mobility between cooperators versus competitors. Academy of Management Journal 51(5): 936-953.

Subramaniam M, Youndt MA. 2005. The influence of intellectual capital on the types of innovative capabilities. Academy of Management Journal 48(3): 450-463.

Summers JK, Humphrey SE, Ferris GR. 2012. Team member change, flux in coordination, and performance: Effects of strategic core roles, information transfer, and cognitive ability. Academy of Management Journal 55(2): 314-338.

Taylor A, Greve HR. 2006. Superman or the Fantastic Four? Knowledge combination and experience in innovative teams. Academy of Management Journal 49(4): 723-740.

Tortoriello M, Reagans R, McEvily B. 2012. Bridging the knowledge gap: The influence of strong ties, network cohesion, and network range on the transfer of knowledge between organizational units. Organization Science 23(4): 1024-1039.

Vough HC, Broschak JP, Northcraft GB. 2005. Here today, gone tomorrow? Effects of nonstandard work status on workgroup processes and outcomes. In Research on Managing Groups and Teams, 7, Neale MA, Mannix EA, Thomas-Hunt M (eds). Elsevier: London; 229-257.

Walker G, Kogut B, Shan W. 1997. Social capital, structural holes and the formation of an industry network. Organization Science 8(2): 109-125.

Wallace M. 1988. Labor market structure and salary determination among professional basketball players. Work and Occupations 15(3): 294-312.

Wernerfelt B. 1984. A resource-based view of the firm. Strategic Management Journal 5(2): 171-180.

White H. 1980. A heteroskedasticity-consistent covariance matrix estimator and a direct test for heteroskedasticity. Econometrica 48(4): 817-838.

White HC. 1981. Where do markets come from? American Journal of Sociology 87(3): 517547.

Wolfe RA, Weick KE, Usher JM, Terborg JR, Poppo L, Murrell AJ, Dukerich JM, Crown Core D, Dickson KE, Simmons Jourdan J. 2005. Sport and organizational studies: Exploring synergy. Journal of Management Inquiry 14(2): 182-210.

Wooldridge JM. 2010. Econometric Analysis of Cross Section and Panel Data. Second edition. MIT Press: Cambridge, MA.

Wright PM, Smart DL, McMahan GC. 1995. Matches between human resources and strategy among NCAA basketball teams. Academy of Management Journal 38(4): 1052-1074.

Zuckerman EW. 2008. Identity imperatives. Working paper. MIT Sloan School of Management: Cambridge, MA. 
Table 1. Descriptive statistics and correlation matrix $(N=960)$

\begin{tabular}{|c|c|c|c|c|c|c|c|c|c|c|c|c|c|c|c|c|c|c|c|c|}
\hline & Mean & S.D. & Min & Max & 1 & 2 & 3 & 4 & 5 & 6 & 7 & 8 & 9 & 10 & 11 & 12 & 13 & 14 & 15 & 16 \\
\hline 1. Organizational performance & -0.01 & 0.66 & -2.13 & 1.97 & & & & & & & & & & & & & & & & \\
\hline 2. Past organizational performance $(\mathrm{t}-2)$ & 0.00 & 0.66 & -2.09 & 1.97 & 0.42 & & & & & & & & & & & & & & & \\
\hline 3. Players' average age & 26.04 & 1.41 & 21.97 & 31.27 & 0.37 & 0.45 & & & & & & & & & & & & & & \\
\hline 4. Players' average tenure with the organization & 1.59 & 0.80 & 0.00 & 4.67 & 0.41 & 0.49 & 0.53 & & & & & & & & & & & & & \\
\hline 5. Players' average experience in the NBA & 3.92 & 1.56 & 0.00 & 9.00 & 0.32 & 0.40 & 0.84 & 0.63 & & & & & & & & & & & & \\
\hline 6. Organizational experience & 25.20 & 16.74 & 0.00 & 65.00 & 0.12 & 0.10 & 0.26 & 0.34 & 0.43 & & & & & & & & & & & \\
\hline 7. Size of organizational core & 5.99 & 0.98 & 3.00 & 10.00 & -0.05 & 0.06 & 0.04 & -0.01 & 0.06 & 0.09 & & & & & & & & & & \\
\hline 8. Size of organizational periphery & 9.07 & 1.67 & 4.00 & 15.00 & -0.22 & -0.12 & 0.03 & -0.18 & 0.00 & 0.09 & -0.40 & & & & & & & & & \\
\hline 9. Coach's tenure with the organization & 2.45 & 2.90 & 0.00 & 22.00 & 0.23 & 0.28 & 0.14 & 0.34 & 0.18 & 0.07 & 0.00 & -0.02 & & & & & & & & \\
\hline 10. Coach's league record & 0.46 & 0.19 & 0.00 & 0.89 & 0.32 & 0.27 & 0.22 & 0.27 & 0.25 & 0.15 & 0.01 & -0.02 & 0.40 & & & & & & & \\
\hline 11. Coach's experience in the NBA & 5.87 & 5.88 & 0.00 & 29.85 & 0.12 & 0.09 & 0.07 & 0.12 & 0.15 & 0.13 & 0.08 & 0.01 & 0.48 & 0.45 & & & & & & \\
\hline 12. Human capital & 11.92 & 4.09 & 0.00 & 18.16 & 0.10 & 0.05 & 0.23 & 0.25 & 0.42 & 0.34 & -0.04 & -0.22 & 0.12 & 0.11 & 0.17 & & & & & \\
\hline 13. Number of newcomers & 5.75 & 2.65 & 0.00 & 16.00 & -0.35 & -0.18 & -0.20 & -0.62 & -0.28 & -0.11 & 0.07 & 0.37 & -0.16 & -0.17 & -0.06 & -0.08 & & & & \\
\hline 14. Relational stability, total & 47.97 & 28.45 & 0.00 & 173.50 & 0.44 & 0.40 & 0.42 & 0.77 & 0.46 & 0.11 & 0.02 & -0.03 & 0.31 & 0.25 & 0.10 & 0.24 & -0.57 & & & \\
\hline 15. Relational stability, core & 12.79 & 11.23 & 0.00 & 72.00 & 0.40 & 0.43 & 0.34 & 0.62 & 0.36 & 0.13 & 0.38 & -0.29 & 0.22 & 0.19 & 0.11 & 0.18 & -0.39 & 0.69 & & \\
\hline 16. Relational stability, periphery & 35.18 & 22.20 & 0.00 & 150.00 & 0.36 & 0.30 & 0.36 & 0.68 & 0.40 & 0.08 & -0.16 & 0.10 & 0.29 & 0.23 & 0.08 & 0.22 & -0.54 & 0.93 & 0.38 & \\
\hline 17. Total payroll & 0.00 & 0.98 & -2.46 & 4.21 & 0.32 & 0.35 & 0.38 & 0.37 & 0.44 & 0.16 & 0.10 & -0.14 & 0.06 & 0.20 & 0.05 & 0.21 & -0.21 & 0.34 & 0.33 & 0.27 \\
\hline
\end{tabular}


Table 2. Results of regression analyses of organizational performance ${ }^{a}$

\begin{tabular}{|c|c|c|c|c|c|c|c|c|c|c|}
\hline & Model 1 & Model 2 & Model 3 & Model 4 & Model 5 & Model 6 & Model 7 & Model 8 & Model 9 & Model 10 \\
\hline Past organizational performance (t-2) & & & & & & & & & & $\begin{array}{l}0.158 * * * \\
(-3.818)\end{array}$ \\
\hline Players' average age & $\begin{array}{c}0.059 \\
(-1.555)\end{array}$ & $\begin{array}{c}0.061 \\
(-1.577)\end{array}$ & $\begin{array}{c}0.050 \\
(-1.247)\end{array}$ & $\begin{array}{c}0.048 \\
(-1.239)\end{array}$ & $\begin{array}{c}0.036 \\
(-0.954)\end{array}$ & $\begin{array}{c}0.026 \\
(-0.574)\end{array}$ & $\begin{array}{c}0.007 \\
(-0.197)\end{array}$ & $\begin{array}{c}0.012 \\
(0.224)\end{array}$ & $\begin{array}{r}-733.8 \\
(-0.111)\end{array}$ & $\begin{array}{l}-0.008 \\
(-0.282)\end{array}$ \\
\hline Players' average tenure with the organization & $\begin{array}{c}0.038 \\
(-0.898)\end{array}$ & $\begin{array}{l}-0.090^{\#} \\
(-1.862)\end{array}$ & $\begin{array}{l}-0.090^{\#} \\
(-1.857)\end{array}$ & $\begin{array}{l}-0.122 * \\
(-2.621)\end{array}$ & $\begin{array}{l}-0.123 * \\
(-2.639)\end{array}$ & $\begin{array}{l}-0.132^{*} \\
(-2.323)\end{array}$ & $\begin{array}{l}-0.098^{*} \\
(-2.519)\end{array}$ & $\begin{array}{l}-0.053^{\#} \\
(-1.721)\end{array}$ & $\begin{array}{r}-3697.0 \\
(-0.909)\end{array}$ & $\begin{array}{l}-0.172 * * \\
(-2.819)\end{array}$ \\
\hline Players' average experience in the NBA & $\begin{array}{c}0.078^{\#} \\
(-1.926)\end{array}$ & $\begin{array}{c}0.062 \\
(-1.479)\end{array}$ & $\begin{array}{c}0.069 \\
(-1.620)\end{array}$ & $\begin{array}{c}0.077^{\#} \\
(-1.901)\end{array}$ & $\begin{array}{c}0.085^{*} \\
(-2.132)\end{array}$ & $\begin{array}{c}0.102^{*} \\
(-2.127)\end{array}$ & $\begin{array}{c}0.088^{*} \\
(-2.205)\end{array}$ & $\begin{array}{c}0.130^{*} \\
(2.080)\end{array}$ & $\begin{array}{c}9892.0 \\
(1.247)\end{array}$ & $\begin{array}{l}0.120 * * * \\
(-3.889)\end{array}$ \\
\hline Size of organizational core & $\begin{array}{l}-0.070^{*} \\
(-2.716)\end{array}$ & $\begin{array}{l}-0.098 * * * \\
(-3.829)\end{array}$ & $\begin{array}{l}-0.106 * * * \\
(-4.244)\end{array}$ & $\begin{array}{l}-0.134 * * * \\
(-5.032)\end{array}$ & $\begin{array}{l}-0.154 * * * \\
(-5.798)\end{array}$ & $\begin{array}{l}-0.164 * * * \\
(-5.243)\end{array}$ & $\begin{array}{l}-0.149 * * * \\
(-7.598)\end{array}$ & $\begin{array}{l}-0.102 * * * \\
(-5.865)\end{array}$ & $\begin{array}{l}-2481.0 \\
(-1.341)\end{array}$ & $\begin{array}{l}-0.171 * * * \\
(-5.648)\end{array}$ \\
\hline Size of organizational periphery & $\begin{array}{l}-0.064 * * * \\
(-3.827)\end{array}$ & $\begin{array}{l}-0.089 * * * \\
(-5.579)\end{array}$ & $\begin{array}{l}-0.095 * * * \\
(-6.178)\end{array}$ & $\begin{array}{l}-0.079 * * * \\
(-5.063)\end{array}$ & $\begin{array}{l}-0.081 * * * \\
(-5.436)\end{array}$ & $\begin{array}{l}-0.083 * * * \\
(-4.943)\end{array}$ & $\begin{array}{l}-0.075 * * * \\
(-6.191)\end{array}$ & $\begin{array}{l}-0.142 * * * \\
(-7.087)\end{array}$ & $\begin{array}{l}-7241.0 * * * \\
(-3.368)\end{array}$ & $\begin{array}{l}-0.090^{* * *} \\
(-5.002)\end{array}$ \\
\hline Number of newcomers & $\begin{array}{l}-0.036^{* *} \\
(-3.121)\end{array}$ & $\begin{array}{l}-0.014 \\
(-1.133)\end{array}$ & $\begin{array}{l}-0.003 \\
(-0.270)\end{array}$ & $\begin{array}{l}-0.018 \\
(-1.469)\end{array}$ & $\begin{array}{l}-0.008 \\
(-0.633)\end{array}$ & $\begin{array}{l}-0.009 \\
(-0.652)\end{array}$ & $\begin{array}{c}0.001 \\
(-0.113)\end{array}$ & $\begin{array}{c}0.014 \\
(0.534)\end{array}$ & $\begin{array}{c}1039.0 \\
(0.408)\end{array}$ & $\begin{array}{c}0.004 \\
(-0.250)\end{array}$ \\
\hline Organizational experience & $\begin{array}{l}0.022 * * \\
(-3.255)\end{array}$ & $\begin{array}{c}0.023 * * \\
(-3.237)\end{array}$ & $\begin{array}{l}0.022 * * \\
(-3.122)\end{array}$ & $\begin{array}{c}0.021^{* *} \\
(-3.016)\end{array}$ & $\begin{array}{c}0.020 * * \\
(-2.886)\end{array}$ & $\begin{array}{c}0.027^{*} \\
(-2.489)\end{array}$ & $\begin{array}{l}0.047 * * * \\
(-4.006)\end{array}$ & $\begin{array}{l}0.538^{* *} \\
(3.082)\end{array}$ & $\begin{array}{c}-104234.0^{* *} \\
(-2.638)\end{array}$ & $\begin{array}{c}0.013^{* *} \\
(-3.108)\end{array}$ \\
\hline Organizational experience (squared) ${ }^{b}$ & $\begin{array}{l}-0.030 * * * \\
(-4.425)\end{array}$ & $\begin{array}{l}-0.033 * * * \\
(-4.442)\end{array}$ & $\begin{array}{l}-0.033 * * * \\
(-4.425)\end{array}$ & $\begin{array}{l}-0.032 * * * \\
(-4.249)\end{array}$ & $\begin{array}{l}-0.031 * * * \\
(-4.177)\end{array}$ & $\begin{array}{l}-0.027^{*} \\
(-2.547)\end{array}$ & $\begin{array}{l}-0.032 * * * \\
(-4.231)\end{array}$ & $\begin{array}{l}-0.099 * * * \\
(-4.545)\end{array}$ & $\begin{array}{l}5504.7 \\
(1.3)\end{array}$ & $\begin{array}{l}-0.019 * * \\
(-2.950)\end{array}$ \\
\hline Coach's tenure with the organization & $\begin{array}{l}-0.001 \\
(-0.138)\end{array}$ & $\begin{array}{l}-0.008 \\
(-0.808)\end{array}$ & $\begin{array}{l}-0.008 \\
(-0.805)\end{array}$ & $\begin{array}{l}-0.005 \\
(-0.612)\end{array}$ & $\begin{array}{l}-0.004 \\
(-0.505)\end{array}$ & $\begin{array}{l}-0.004 \\
(-0.358)\end{array}$ & $\begin{array}{l}-0.008 \\
(-1.213)\end{array}$ & $\begin{array}{l}-0.030 \\
(-1.432)\end{array}$ & $\begin{array}{r}575.4 \\
(0.201)\end{array}$ & $\begin{array}{c}0.002 \\
(-0.277)\end{array}$ \\
\hline Coach's league record & $\begin{array}{l}0.491 * * * \\
(-4.981)\end{array}$ & $\begin{array}{l}0.431 * * * \\
(-4.348)\end{array}$ & $\begin{array}{l}0.432 * * * \\
(-4.575)\end{array}$ & $\begin{array}{l}0.417 * * * \\
(-4.387)\end{array}$ & $\begin{array}{l}0.391 * * * \\
(-4.318)\end{array}$ & $\begin{array}{l}0.491 * * * \\
(-4.096)\end{array}$ & $\begin{array}{c}0.238^{* *} \\
(-2.578)\end{array}$ & $\begin{array}{l}0.047^{* *} \\
(2.623)\end{array}$ & $\begin{array}{l}4149.0^{*} \\
(2.092)\end{array}$ & $\begin{array}{l}0.338^{* * *} \\
(-4.445)\end{array}$ \\
\hline Coach's experience in the NBA & $\begin{array}{c}0.006 \\
(-1.558)\end{array}$ & $\begin{array}{c}0.008^{\#} \\
(-1.823)\end{array}$ & $\begin{array}{c}0.008^{\#} \\
(-1.788)\end{array}$ & $\begin{array}{c}0.007 \\
(-1.553)\end{array}$ & $\begin{array}{c}0.007 \\
(-1.545)\end{array}$ & $\begin{array}{c}0.002 \\
(-0.493)\end{array}$ & $\begin{array}{r}0.007^{*} \\
(-2.149)\end{array}$ & $\begin{array}{c}0.044 * \\
(2.253)\end{array}$ & $\begin{array}{l}2581.0 \\
(0.986)\end{array}$ & $\begin{array}{c}0.002 \\
(-0.513)\end{array}$ \\
\hline Human capital & $\begin{array}{l}0.090 * * * \\
(-4.206)\end{array}$ & $\begin{array}{l}0.090 * * * \\
(-4.291)\end{array}$ & $\begin{array}{l}0.090 * * * \\
(-4.282)\end{array}$ & $\begin{array}{l}0.092 * * * \\
(-4.492)\end{array}$ & $\begin{array}{l}0.091 * * * \\
(-4.388)\end{array}$ & $\begin{array}{l}0.083 * * * \\
(-4.329)\end{array}$ & $\begin{array}{l}0.077 * * * \\
(-5.707)\end{array}$ & $\begin{array}{l}0.304 * * * \\
(5.418)\end{array}$ & $\begin{array}{l}13644.0^{*} \\
(2.180)\end{array}$ & $\begin{array}{l}0.107 * * * \\
(-4.235)\end{array}$ \\
\hline Relational stability, total & & $\begin{array}{l}0.006 * * * \\
(-6.254)\end{array}$ & $\begin{array}{l}0.008 * * * \\
(-8.477)\end{array}$ & & & & & $\begin{array}{l}0.196^{* * *} \\
(6.410)\end{array}$ & $\begin{array}{l}9996.0 * * * \\
(3.330)\end{array}$ & \\
\hline Relational stability, total (squared) ${ }^{\mathrm{b}}$ & & & $\begin{array}{l}-0.004 * * \\
(-3.218)\end{array}$ & & & & & $\begin{array}{l}-0.024 * \\
(-2.369)\end{array}$ & & \\
\hline Relational stability, core & & & & $\begin{array}{l}0.014 * * * \\
(-7.803)\end{array}$ & $\begin{array}{l}0.021 * * * \\
(-8.158)\end{array}$ & $\begin{array}{l}0.021 * * * \\
(-6.679)\end{array}$ & $\begin{array}{l}0.018 * * * \\
(-7.070)\end{array}$ & & & $\begin{array}{l}0.021 * * * \\
(-5.886)\end{array}$ \\
\hline Relational stability, core (squared) $^{\text {b }}$ & & & & & $\begin{array}{l}-0.031 * * * \\
(-4.185)\end{array}$ & $\begin{array}{l}-0.034 * * * \\
(-4.369)\end{array}$ & $\begin{array}{l}-0.022 * * \\
(-2.904)\end{array}$ & & & $\begin{array}{l}-0.027^{*} \\
(-2.454)\end{array}$ \\
\hline Relational stability, periphery & & & & $\begin{array}{l}0.004 * * \\
(-3.620)\end{array}$ & $\begin{array}{l}0.004 * * * \\
(-3.979)\end{array}$ & $\begin{array}{r}0.003^{*} \\
(-2.052)\end{array}$ & $\begin{array}{c}0.004 * * \\
(-3.073)\end{array}$ & & & $\begin{array}{l}0.005 * * * \\
(-3.771)\end{array}$ \\
\hline Relational stability, periphery (squared) ${ }^{b}$ & & & & & $\begin{array}{l}-0.002 \\
(-1.017)\end{array}$ & & $\begin{array}{l}-0.002 \\
(-1.140)\end{array}$ & & & \\
\hline Total payroll & & & & & & $\begin{array}{c}0.071^{\#} \\
(-1.855)\end{array}$ & & & & \\
\hline Total payroll (squared) & & & & & & $\begin{array}{l}-0.034^{*} \\
(-2.320)\end{array}$ & & & & \\
\hline Club fixed effects & Yes & Yes & Yes & Yes & Yes & Yes & Yes & Yes & Yes & Yes \\
\hline Year fixed effects & Yes & Yes & Yes & Yes & Yes & Yes & Yes & Yes & Yes & No \\
\hline Constant & $-2.331 * *$ & $-1.790 *$ & $-1.423 \#$ & -1.287 & -0.845 & -0.827 & $-1.685^{\#}$ & $-0.847^{*}$ & $712,163 * * *$ & 0.072 \\
\hline Observations (club-year) & 960 & 960 & 960 & 960 & 960 & 707 & 960 & 960 & 959 & 944 \\
\hline Number of teams & 30 & 30 & 30 & 30 & 30 & 30 & 30 & 30 & 30 & 30 \\
\hline $\mathrm{BIC}$ & 1511.624 & 1475.726 & 1466.845 & 1458.047 & 1442.772 & 1361.404 & - & - & - & - \\
\hline Estimation procedure & OLS & OLS & OLS & OLS & OLS & OLS & GLS & GLS & GLS & $\mathrm{AB}$ \\
\hline Panel Heteroskedastic & Yes & Yes & Yes & Yes & Yes & Yes & Yes & Yes & Yes & Yes \\
\hline Robust Standard Errors & Yes & Yes & Yes & Yes & Yes & Yes & No & No & No & Yes \\
\hline AR1 Autocorrelation Structure & No & No & No & No & No & No & Yes & Yes & Yes & - \\
\hline Standardized coefficients & No & No & No & No & No & No & No & Yes & Yes & No \\
\hline
\end{tabular}




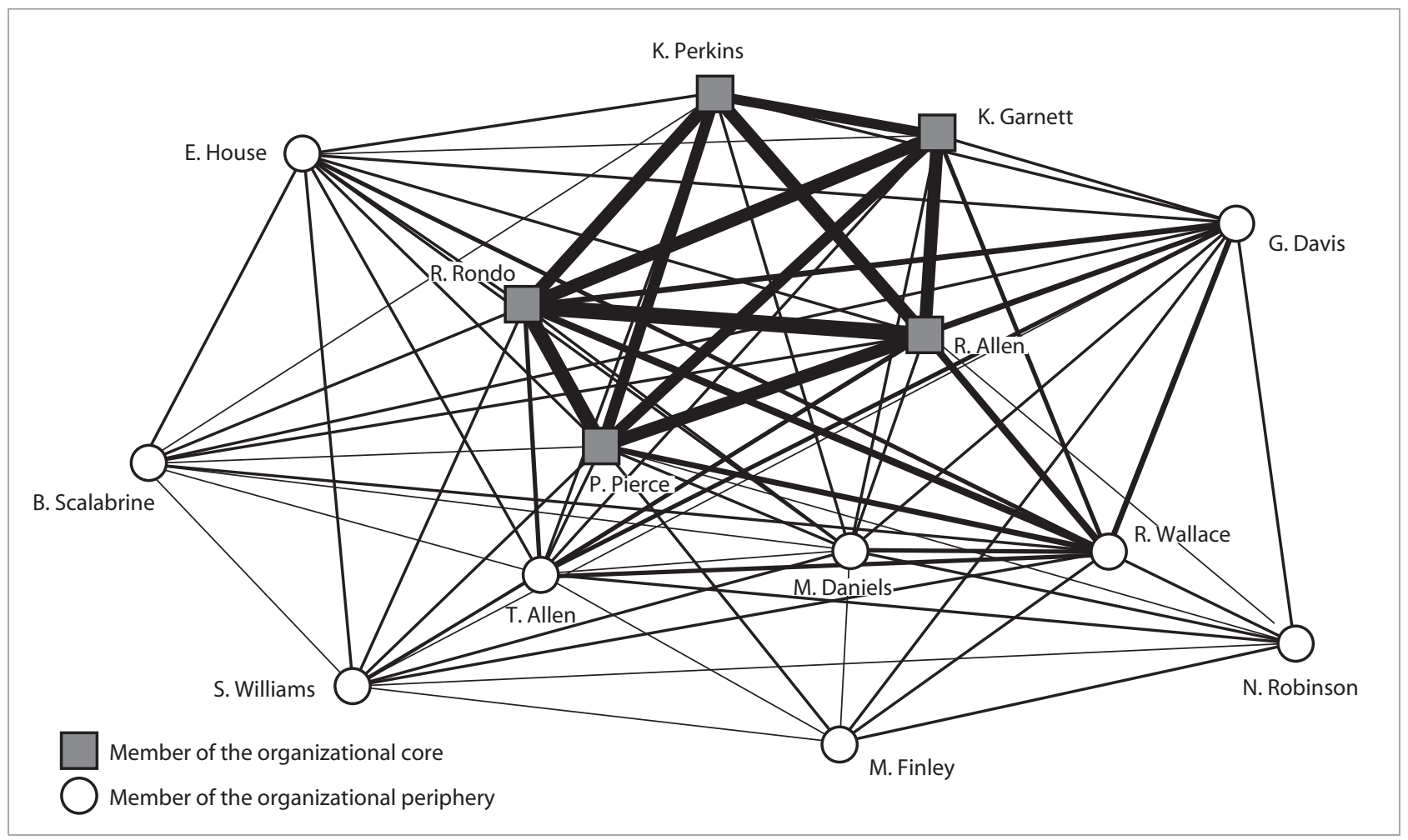

Figure 1. Interdependency network of the 2009/2010 Boston Celtics

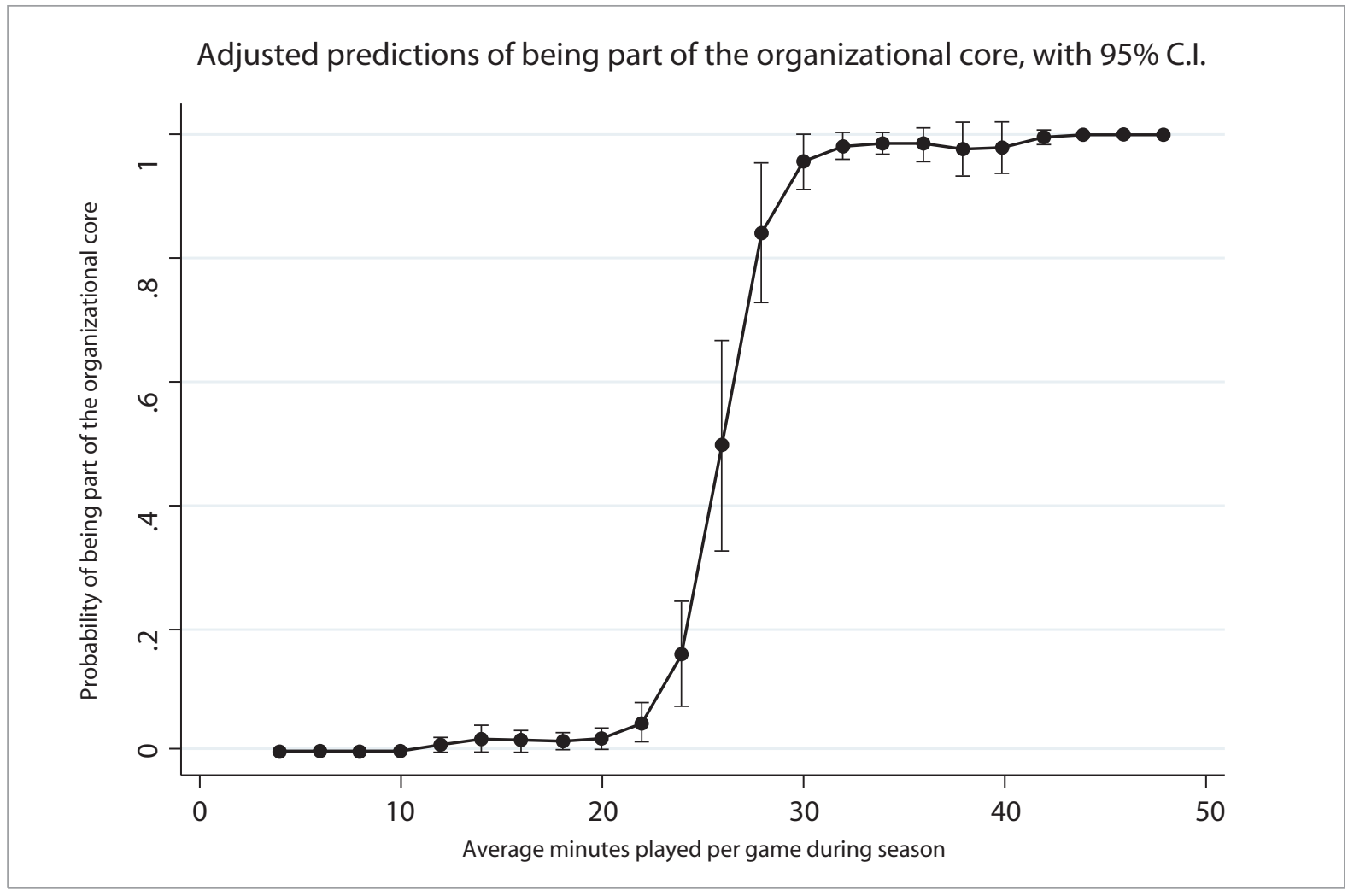

Figure 2. Predicted probabilities of being part of the organizational core by average minutes played 

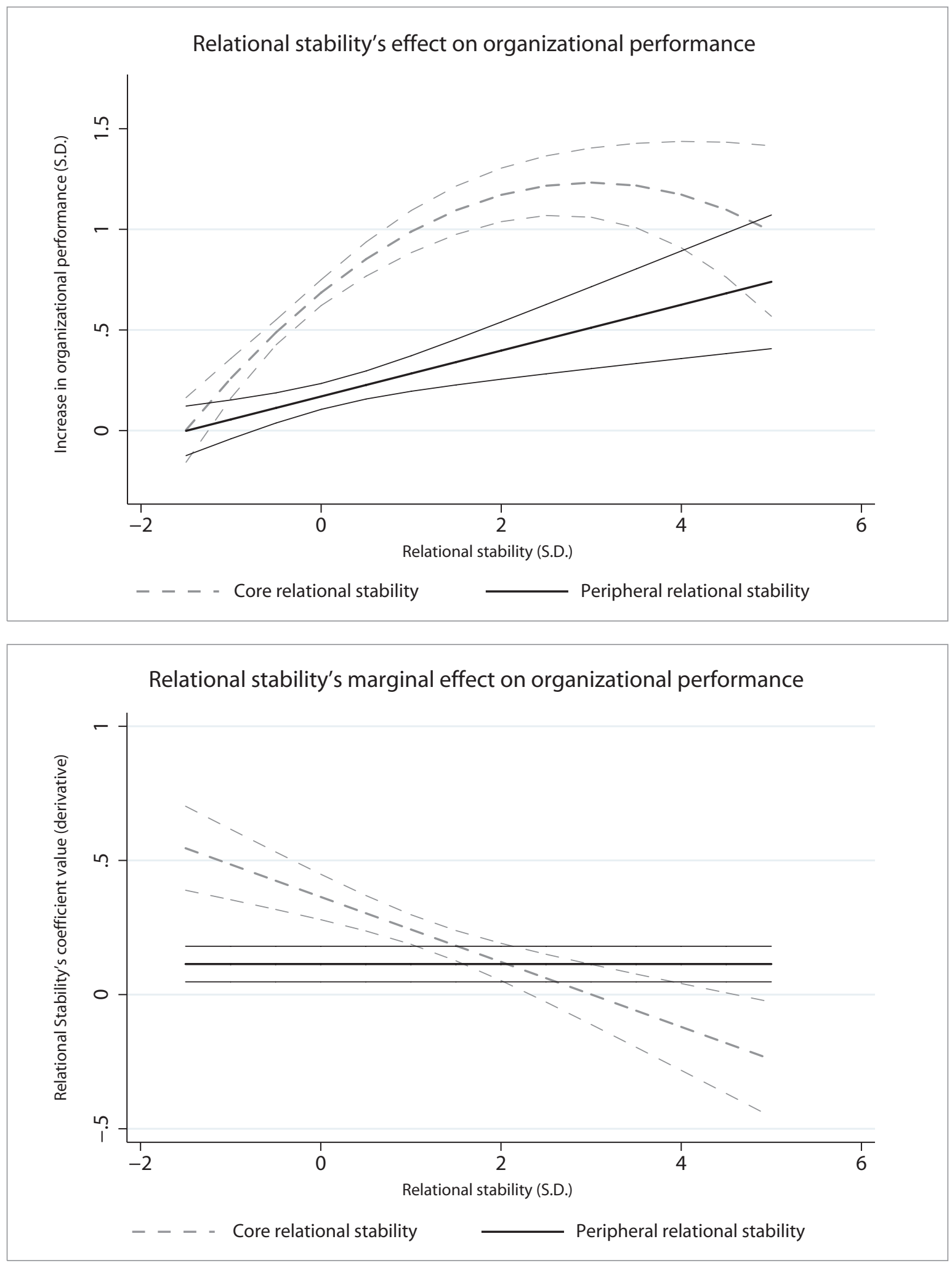

Figure 3a and 3b. Relational stability's effect (3a) and its marginal returns (3b) on organizational performance 


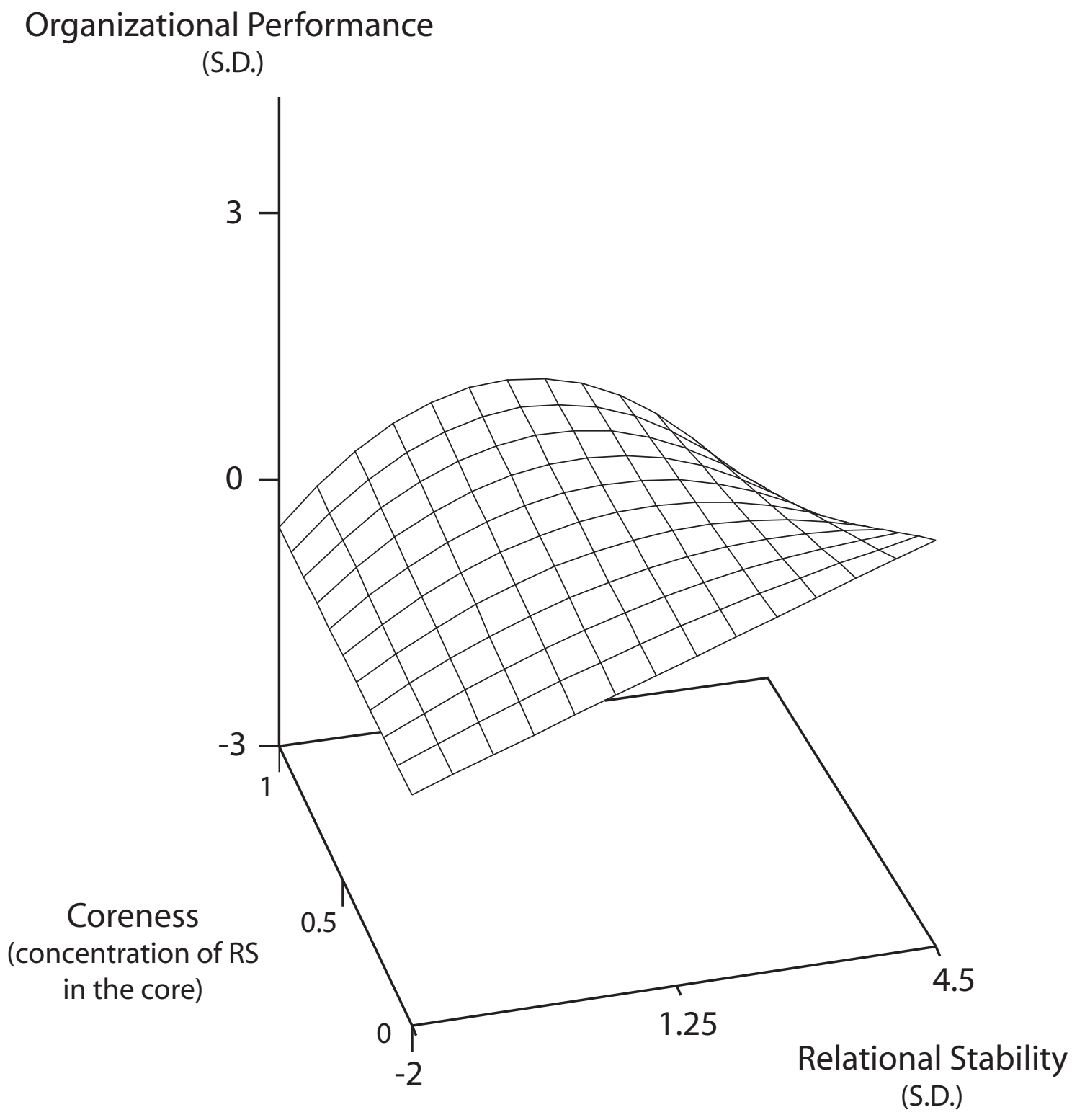

Figure 4. Regression surface of moderated curvilinearity analysis 